\title{
Faculty Development For Learning: The Promise of Classroom Research
}

\section{Thomas A. Angelo}

University of California, Berkeley

Before the 1980's reach their close, I propose we decide to make the 1990's the decade of faculty development for learning. The next few years will offer faculty development specialists an unparalleled opportunity to improve the quality of learning in higher education, thanks to the confluence of powerful trends in educational policy, funding, demographics, and research. Faculty developers can make the most of this opportunity by focusing their individual and collective energies on a common goal: Improving the quality of learning in higher education.

At first glance, this proposal may seem to be no more than a new label for old wine in an equally old bottle. There are two main reasons why that is not the case. First, the primary focus of most faculty development programs has traditionally been on teaching and teachers, not on learning and learners. Second, in arguing that the central goal of faculty development should be to improve the quality of learning, I mean more than simply improving the quality of student learning of course-related knowledge and skills or of faculty learning of disciplinary knowledge and teaching skills.

The faculty development agenda for the 1990's proposed in this article would stretch our concept of learning to include two relatively unexplored dimensions. First, it would encourage and enable faculty and students to improve the quality of what they learn about learning. This improvement can be brought about by training faculty to assess their teaching effectiveness systematically and regularly. At the same time, faculty developers can help faculty teach students to become more selfaware, self-directed, and effective learners. 
Second, faculty developers can take the lead in improving the quality of what the teaching profession learns about effective practice in college teaching and learning. While we now have some useful general principles for effective teaching based on research (Gamson and Chickering, 1987; Murray, 1985), we need to begin developing detailed, discipline-specific knowledge bases to inform instructional improvement programs for experienced teachers, new teachers, and graduate teaching assistants.

Faculty development programs can help bring this about by providing training and support for research by faculty on teaching and learning in specific disciplinary contexts and by creating networks to collect and share the learning that results. By the year 2000, faculty developers and college teachers working together could build a firm foundation of practical knowledge about teaching and learning in a number of disciplines. Such a collection of disciplinary knowledge bases would make real progress in teaching improvement possible by freeing future college teachers from having to "reinvent the wheel," as each generation before them has done.

This article will explain why faculty developers should make learning improvement their primary goal and suggest guidelines for achieving that goal. Specifically, it proposes Classroom Research as an approach wellsuited to improving the quality of student learning, promoting teacher and student self-awareness, and building practical knowledge bases about teaching and learning in the disciplines.

I will begin by reviewing four trends that will make the 1990's a particularly promising time to improve college learning. Second, I will explain why faculty development should focus on learning and why instructional improvement programs should reconsider some of their current approaches. I will then describe seven "barriers" that hamper the effectiveness of many current teaching improvement efforts and propose seven guidelines to overcome those barriers. Next, I will identify five common approaches to teaching improvement and consider how well each approach meets the guidelines proposed. Fifth, I will provide a working definition of Classroom Research and briefly explain the University of California, Berkeley Classroom Research Project's approach to faculty training. Finally, I will make a case for Classroom Research as a practical, learning-centered approach to faculty development that can effectively overcome many of the previously mentioned barriers. 


\section{Why the 1990's Represent a Unique Opportunity for Faculty Developers}

During the next few years, four powerful, interrelated trends will create favorable conditions for improving teaching and learning in higher education. These trends are (a) the widespread public concern with the quality of higher education; (b) the increasing level of competition for public and private funding; (c) the changing demographics of students and professors; and (d) the development of a body of useful, relevant research about college teaching and learning.

The higher education reform reports of the mid-1980's, such as $A$ Nation at Risk (National Association for Excellence in Education, 1983) and Integrity in the College Curriculum (Association of American Colleges, 1985) signalled a shift in focus from concerns with quantity, defined as access to higher education, to a focus on the quality of college outcomes. The earlier public policy goal of "equal access for all" has moved closer to one of "access to a quality education for each." To some degree, this change can be understood by looking at higher education as a maturing market. As with many once-scarce goods, when the quantity of higher education became sufficient to meet consumer demand, product quality became the dominant focus. At the same time, widespread concern about U.S. economic and scientific competitiveness added political dimensions to the education question, transforming what had been an "in-house" discussion on the quality of student learning into a major public policy issue.

During the 1980's, a number of new public priorities have emerged to compete with higher education for available funds. Governments and foundations have begun to respond to public pressure by allocating funds to clean up the environment, provide more health care for an aging population, and fight drug abuse and related problems. At the same time that the Reagan Administration was raising defense-related spending and cutting federal funding for higher education, many state and local governments were faced with real and threatened tax "revolts." Responding to public pressure and fiscal restraints, legislators and governors balked at budget requests for higher education and demanded more accountability.

These economic pressures, together with the focus on quality, have generated and fueled the "Assessment Movement" that has swept the states in the last five or so years. Documenting how much and how well students are learning is the primary focus of these state-mandated assessments. Thus, to compete successfully for funds, colleges and universities 
are finding it increasingly necessary to demonstrate that they are providing a high-quality education and that their students are indeed learning.

Changing student demographics favor an emphasis on quality. As well as competing for a smaller share of available funds, public and private institutions are competing for a smaller pool of 18- to 24-year-olds. At the same time, high school seniors today are more likely to have college-educated parents than any previous generation. As a result, they and their parents are well-informed and demanding "consumers" of higher education, as are the adult learners who have entered college in ever greater numbers. For all of these reasons, colleges and universities now have to "sell" the quality of their "product" as never before to legislators, foundation officers, parents, prospective students, and the taxpaying public.

The demographics of the professoriate will also play a role in stimulating demand for faculty development to improve teaching and learning. The World War II generation of G.I. Bill faculty is already retiring, with the Korean War "wave" right behind them. Nationwide, within the next fifteen years, roughly half the present college faculty will reach retirement age (Carnegie, 1988). Most of the faculty hired to replace them will have had no more teaching preparation than their predecessors - that is, little or none. Nevertheless, in all types of institutions, new faculty will be expected to demonstrate their teaching competence more explicitly and more often than did their veteran colleagues. It is very likely that the quality of faculty teaching will play a greater role in tenuring and promotion in the 1990's than ever before, even though the focus on research and publication is unlikely to diminish.

The fourth trend in support of quality is the explosion of knowledge about teaching and learning. We now have a large and growing research base that can inform and could influence college teaching. During the past three decades, much has been discovered about human learning in general and about college student learning in particular (McKeachie et al., 1986). Solid research by cognitive scientists, educational psychologists, ethnographers, and other qualitative researchers can offer much more direction to college teachers of the 1990's than was available in the past. Much still needs to be done, however, to make this research available and useful to college teachers, as well as to determine its implications for various contexts, subpopulations, and disciplines. Faculty developers can and should play a central role in applying this hard-won knowledge to the classroom. 


\section{Why Faculty Development Should Focus on Improving Learning}

Although most faculty developers will argue, correctly, that improving student learning has always been one of their goals, it has not usually been their primary goal. More often, in fact, faculty development programs support faculty in their non-teaching roles. Faculty development, after all, means different things to different people, and faculty development as instructional improvement is only one of five common approaches (Mathis, 1982). The other four focus on professional, curricular, organizational, and personal development. In many cases, these other approaches tend to take faculty away from the classroom through leaves and sabbaticals, travel grants, reduced teaching loads, or limited released time to attend conferences, workshops, and training seminars. Of the five approaches, only faculty development as instructional development directly aims to improve teaching and learning at the classroom level.

While support for faculty efforts to do research, publish, stay current in their fields, revise and refine the curriculum, improve departmental functioning, or build personal and interpersonal skills may contribute indirectly to better teaching and, ultimately, more effective learning, there is little evidence so far that they do. More to the point, we know little about how instructional improvement and teaching effectiveness programs affect student learning - or if they do. Faculty developers, on the whole, have been more successful at implementing innovations than at determining their usefulness.

Faculty development, having weathered twenty turbulent years of growth and retrenchment in higher education, is likely to survive into the foreseeable future. But as the faculty development "movement" enters its third decade, its goal should not be merely to survive, but to thrive. In order to thrive and to reach maturity as a professional field in the 1990's, faculty development must successfully meet three challenges. First, faculty developers must clearly define program goals and demonstrate how those programs can help college faculty achieve their goals. Next, they must convince a larger fraction of the faculty to collaborate systematically to achieve those shared goals. Third, faculty developers must provide effective leadership, training, and support for such collaborative efforts.

In a nutshell, to take advantage of this "golden opportunity" to improve learning in higher education, faculty developers need to develop credibility and trust among faculty, foster a shared commitment to improve student learning, and design clear paths to reach that goal. 


\section{Why Faculty Developers Should Reconsider Some of Their Current Approaches to Instructional Improvement}

Faculty development efforts aimed at improving college teaching have found homes on many campuses. The desirability of such efforts is widely recognized by administrators, by students, and by faculty - who are generally quick to acknowledge that their colleagues need such help, even though they themselves do not. Judging from the informal reports of my colleagues, however, campus-wide instructional improvement programs generally suffer from two related problems: first, a relatively small percentage of the faculty takes advantage of these programs; and second, those who participate most in teaching improvement efforts are often those who seem to need them least.

Yet most faculty view teaching, not research, as their primary role (Carnegie, 1985). If we assume that most college teachers are motivated to teach well, why do so few participate in instructional improvement programs? This general reluctance to participate is not simply a product of faculty complacency or intransigence, although these attitudes certainly contribute to it in some cases. Nor can we attribute it to the conflict between teaching and research, except perhaps for untenured faculty at research universities. Lack of time is the most common reason given for not participating, but that response simply begs the question of priorities. Since all college teachers must make choices about how to invest their time, why do a few become involved in instructional development, while most do not?

\section{Seven Barriers to More Widespread and Effective Faculty Participation in Teaching/Learning Improvement Programs}

One reason for limited faculty participation may be that most teaching improvement programs have significant barriers to faculty participation unwittingly built into their frameworks. These barriers serve as "disincentives" to faculty investment of time and effort by lowering the expected benefits of participation or raising the expected costs, or both. To involve a greater percentage of the faculty in actively improving teaching and learning in the 1990's, faculty developers must recognize and remove, or at least lower, the sever common barriers discussed below. 


\section{Most faculty development programs focus primarily on teaching and only secondarily on learning.}

As noted earlier, most faculty development efforts emphasize the improvement of teaching and focus on teacher knowledge, skills, attitudes, and behaviors. While improving teaching is one means to improve student learning, and a very powerful one, it is not the only means. For example, in many cases learning may be more effectively improved by helping students develop their study skills and strategies than by changing teacher behaviors. So, programs that focus primarily on improving teaching may not be the most effective in improving the quality of student learning.

Second, by focusing on teaching and teachers, rather than on learning and learners, faculty development programs may inadvertently undermine faculty status and professional autonomy. Participation in teaching improvement programs may threaten faculty with real or perceived loss of status. Some faculty see participation in such programs as a tacit admission of inadequacy or failure - as an indication that they need help, or at least that they lack confidence in their teaching performance. This is especially likely if the faculty development specialist is perceived as having lower status than the instructor who is seeking help or advice. Since status relationships are critically important in academic life, any situation that threatens faculty status is likely to be avoided.

Another very central characteristic of academic culture is professional autonomy, one element of academic freedom. College faculty are used to working alone and unquestioned. In general, collaboration is not a skill much valued in graduate school. While pursuing their doctorates, and especially in writing dissertations, academics must demonstrate selfsufficiency and endure isolation. Most college teachers are used to developing and teaching courses entirely on their own, not to depending on or even turning to others for help or advice.

Participation in instructional improvement programs that involve videotaping, observation by faculty developers or peers, or student evaluation can threaten the college teacher's sense of professional autonomy and control over the classroom. Within this framework, even well-meant suggestions for improvement may be seen as intrusions and resented as such. Whenever possible, faculty will tend to avoid programs that threaten their sense of professional autonomy. 


\section{Most faculty are not actively and consistently aware of what, how, and how well their students are learning.}

Most college teachers have had little or no formal training in assessing student learning. At the same time, they often have limited experience in explicitly identifying and diagnosing teaching and learning problems, and even less experience in discussing them productively with other teachers. When faculty do meet to discuss educational matters, a rather rare occurrence, it is usually to consider the content or structure of the curriculum or to set requirements - not to talk about classroom teaching and learning. Therefore, it should come as no surprise that many college teachers cannot or do not "see" the problems their students have with learning course material. Until faculty can see those problems for themselves, which is not at all the same as having those problems pointed out by others, there is little use in trying to interest them in solutions.

\section{Many programs do not explicitly recognize and respect discipline- specific "ways of knowing."}

Teaching improvement programs often fail to take into account the discipline-specific nature of college teaching and of faculty thinking. College faculty develop their ways of knowing, of learning, and of teaching within disciplinary frameworks (Eisner, 1985). As a consequence, the intellectual "world view" of a biologist is likely to be quite different than that of a specialist in English literature, a psychologist, or even a chemist. At the same time, the skills and knowledge required for success differ greatly from field to field. As a result, teaching and learning have their own particular characteristics in each academic field and represent particular challenges.

Thus, it should not surprise us that many faculty are skeptical or downright dismissive of the idea that anyone outside their academic discipline can understand its specific teaching and learning issues. Even the most intelligent, open-minded faculty often have trouble understanding the relevance of teaching innovations or suggestions presented by teachers from other disciplines. This is not because faculty are being obtuse or resistant. Rather, it is because those ideas must first be translated into the relevant disciplinary terms and concepts before they can be understood or acted upon. That translation is most powerful and convincing when faculty make it for themselves by identifying analogous issues within their own teaching fields. 


\section{Many faculty do not see the relevance of instructional improvement programs to their own teaching.}

While this barrier is related to, and sometimes exacerbated by, a lack of translation across different disciplinary "ways of knowing," it has more to do with the needs of individual teachers and the dynamic of their classes. The generic nature of many faculty development efforts, such as presentations and workshops, often does not respond to the teacher's highly personal and specific agenda. Faculty concerns tend to be problem-centered, while faculty development programs are often topiccentered. Even when discussion or training sessions are explicitly problem-centered, it is usually the faculty developer or presenter who has defined the agenda, and not the teachers. Faculty are understandably reluctant to commit time and energy to programs that are not obviously and directly related to their immediate, very personal teaching goals and needs.

\section{Many programs do not capitalize effectively on intrinsic motivation.}

College teachers are, by and large, closer to the intrinsic end of the motivation scale than are members of most other professions. By their very choice of vocation, faculty have indicated that they are not likely to be highly motivated by extrinsic rewards (McKeachie, 1979). They are much more likely to be powerfully motivated by intellectual challenge, the freedom to define and solve problems of their own choosing, and the fulfillment that comes from helping students learn and develop.

This does not mean that money and recognition cannot motivate faculty. They obviously can. But in terms of their power to change teaching behaviors and improve learning, extrinsic rewards probably have little effect. Identifying and rewarding outstanding teachers with public praise and cash awards is not necessarily a bad idea, but it is unlikely to motivate the winners or their colleagues to teach better once the ceremony is over. Under most circumstances, it is equally unlikely that releasing faculty from teaching will improve their classroom performances.

\section{Many programs lack enough explicit links to intellectual substance to be taken seriously by faculty.}

College faculty respect scholarship and expect the faculty developer's recommendations to be grounded in solid thinking and, whenever possible, supported by evidence. As noted above, a great deal of good research on teaching and learning does exist, and many faculty development efforts are solidly grounded in that research. Too often, however, 
the faculty who are asked to participate are not made aware of the scholarship behind the innovations being proposed. Only intellectually substantive, credible programs are likely to convince the majority of faculty members to change deep-rooted attitudes and teaching behaviors. Instructional development efforts that are perceived as "content-less" or "content-light," or as manifestations of educational fads, will be shunned.

7. Many programs lack sufficient planning, structure, support, and follow-through to be effective over the long term.

The dispositions, attitudes, and habits that guide so much of teaching behavior develop over many years, beginning with the future teacher's college experience or before. Any program that seeks to change teaching behavior must plan for the long term. While college faculty do not accept having structure imposed on them, they tend not to take unstructured activities seriously. They want to be associated with well-planned, substantial, well-organized enterprises. Many faculty development programs undercut their possible effectiveness by failing to invest sufficiently in advance planning and ongoing support for a few long-term efforts, choosing instead to offer a larger number of less demanding one-shot or short-term options.

\section{Seven Guidelines for More Effective Faculty Development to Improve Teaching and Learning}

Once the barriers to faculty involvement have been recognized, the challenge is to overcome or lower them. The seven guidelines below parallel and respond to the seven barriers discussed above. I suggest that by following these guidelines, faculty developers can increase both the quantity and quality of faculty participation in instructional improvement programs. With more and better participation, efforts to improve teaching and learning are more likely to succeed.

1. Focus on improving learning as the primary goal, and on improving teaching as one means to achieve that goal.

By focusing programs directly on improving learning, faculty developers can avoid or ameliorate many of the barriers listed above. First, making improved learning the goal of instructional development focuses everyone' $[s$ attention on the desired outcome and encourages a wider range of approaches to achieving that goal. Second, focusing on learning is more inclusive than focusing on teaching. The former can 
involve administrators, faculty, and students in a common enterprise, while the latter includes only faculty. In a related way, focusing on learning improvement encourages students to accept some responsibility for the outcomes of their classroom experiences. Third, focusing on learners and learning is less likely to threaten faculty status and professional autonomy than focusing on teachers and teaching.

\section{Help faculty develop simple and effective ways to assess learning.}

Build self-awareness by encouraging and assisting faculty to become skilled observers of their teaching and assessors of its effects on student learning. Provide practical, ongoing training, support, and consultation for teachers who are interested in learning to assess student learning more effectively.

\section{Respect and capitalize on discipline-specific "ways of knowing."}

Respect discipline-specific ways of knowing by recognizing faculty members as teaching and learning "experts" in their fields. Encourage faculty to adapt and apply the discipline-specific research skills they already have to studying and improving learning in their classrooms. Capitalize on shared "world views" by organizing project working groups along disciplinary and departmental lines.

\section{Build in personal investment and faculty ownership.}

Build in personal investment by helping individual faculty members define and pursue questions and problems they want to address. Provide a clear procedure through which the participating faculty can set the agenda for individual and collaborative learning improvement efforts.

Respect faculty autonomy by allowing and encouraging total faculty ownership of learning improvement programs. Let faculty participants in each program determine the appropriate level of administrator involvement.

\section{Appeal to a broad range of motivations.}

Capitalize on intrinsic motivation by focusing on teaching and learning issues that capture the intellectual interest of faculty. Build in regular success by offering clear-cut, step-by-step procedures to help faculty set and achieve their goals and objectives. Help faculty collaborate productively with departmental colleagues, as well as with others from across the disciplines. Faculty often find the rewards of such collaboration highly motivating. 
Recognize and praise participants publicly for their interest, involvement, and efforts. Encourage risk-taking and experimentation, and not just success. This type of extrinsic motivation costs little or nothing and yields many benefits. When funds are available for Classroom Research, consider providing support for clerical help and research assistants, rather than directly subsidizing faculty participation.

\section{Build in intellectual substance.}

Whenever possible, explicitly make connections to the relevant research on teaching and learning. Be prepared to justify and explain the goals and methods of programs in terms the faculty will understand and accept. Provide references and short readings when appropriate, even if you suspect many faculty will not read them. Journals and newsletters devoted to teaching in specific disciplines are often good sources for such material.

\section{Plan and implement for long-term success.}

Allow adequate planning time, secure necessary human and material support, and provide a well-organized but flexible process within which faculty can develop and accomplish their own agendas. To ensure their ongoing involvement, encourage participants to start small, to build incrementally, and to set limits on the amount of time and energy they will invest in such programs.

\section{The Five Most Common Approaches to Instructional Improvement}

Based on my observations and experiences, I have categorized faculty development programs to improve teaching and learning into five broad approaches. The five approaches, named for the characteristic types of services offered by each, are: Inspiration/Information; Rewards and Recognition; Specific Skills Training; Clinical/Research Consultation; and Peer-Coaching/Mentorship. Many, if not most, instructional development programs make use of more than one of these approaches.

Figure 1 presents some of the defining characteristics of these five approaches. The Inspiration/Information approach relies mostly on speeches and lecture-demonstrations by teaching "experts." These experts may be the faculty developers themselves, winners of local teaching excellence awards, or nationally recognized authorities. The aims of this approach are to inform faculty how to teach more effectively and to inspire 
them to accept excellent teaching as a goal worth working toward. These presentations are usually one-shot affairs, often without organized followup activities. At times, however, they are effectively integrated into ongoing teaching improvement programs or used as kick-off events. In general, faculty play a rather passive role in Information/Inspiration sessions, with participation usually limited to asking questions of the speaker.

The second approach, Rewards and Recognition, probably requires little explanation. In such programs, a given number of "excellent teachers" are chosen each year from among the faculty. While these award-winners are often nominated and selected by the faculty itself, at some colleges students and administrators influence or control their selection. The primary purpose of such programs is to recognize and reward good teaching. The hope is that these superior teachers, once honored, will influence other faculty members by example, and that others will aspire to this honor. Faculty developers are often called upon to create and organize these efforts and usually influence the criteria for nomination. Most of the time the role of the faculty is limited to nominating, voting for, and applauding their honored colleagues.

Specific Skills Training programs cast the faculty in the more active roles of learners and trainees. The purpose of such programs is, as the name makes clear, to develop skills for more effective teaching. Workshops, seminars, and institutes provide training in test construction, teaching techniques, writing-across-the-curriculum, and the like. Faculty developers organize and often lead the training sessions.

Clinical Consultation can put the faculty developer in the highly personal role of therapist, advisor, or problem-fixer. Technical Consultation is normally less personal, centering on improving teaching techniques or introducing technology. In either case, the consultative relationship is usually one-on-one, and may be short- or long-term. In contrast to the three approaches mentioned above, the faculty "clients" often set the agenda in Clinical/Technical Consultation. As "clients," faculty may be referred to the faculty developer due to observed problems or poor evaluations, or may seek out assistance on their own. These self-motivated clients are, in fact, often among the most successful and dedicated teachers.

The fifth approach, Mentorship and Peer-Coaching, shares its oneon-one, face-to-face orientation with the consulting approach, but in this case, the "helping other" is another faculty member, usually from the same academic field. The faculty developer's role is largely that of matchmaker, connecting the appropriate people. Although coaching is a part 
of both Mentorship and Peer-Coaching, the two-way, role-trading nature of the relationship between collaborators in Peer-Coaching makes it a partnership of equals. In Mentoring, however, the mentor is often older and usually higher in status. The mentee, most often a new faculty member, serves a kind of apprenticeship, learning by watching, working with, and talking with the "master" teacher. The purpose of both types of arranged partnerships is to help teachers learn from their colleagues.

\section{FIGURE 1}

Characteristics of Five Common Approaches to Instructional Development

\begin{tabular}{|c|c|c|c|}
\hline Approach & $\begin{array}{l}\text { Commonly Used } \\
\text { Techniques }\end{array}$ & $\begin{array}{l}\text { Characteristic } \\
\text { Role of Faculty } \\
\text { Developer or } \\
\text { Consultant }\end{array}$ & $\begin{array}{l}\text { Characteristic } \\
\text { Role of } \\
\text { Participating } \\
\text { Faculty } \\
\text { Members }\end{array}$ \\
\hline $\begin{array}{l}\text { Information/ } \\
\text { Inspiration }\end{array}$ & $\begin{array}{l}\text { Speeches, } \\
\text { Lectures, and } \\
\text { Teaching } \\
\text { Demonstrations }\end{array}$ & $\begin{array}{l}\text { Organizer/ } \\
\text { Speaker/ } \\
\text { Presenter }\end{array}$ & Audience \\
\hline $\begin{array}{l}\text { Rewards and } \\
\text { Recognition }\end{array}$ & $\begin{array}{l}\text { Cash Awards } \\
\text { Citations and } \\
\text { Ceremonies }\end{array}$ & $\begin{array}{l}\text { Organizer/ } \\
\text { Criteria-Seeker }\end{array}$ & $\begin{array}{l}\text { Electors, } \\
\text { Audience and } \\
\text { Recipients }\end{array}$ \\
\hline $\begin{array}{l}\text { Specific Skills } \\
\text { Training }\end{array}$ & $\begin{array}{l}\text { Workshops and } \\
\text { Seminars }\end{array}$ & $\begin{array}{l}\text { Organizer/ } \\
\text { Trainer }\end{array}$ & Trainees \\
\hline $\begin{array}{l}\text { Clinical/ } \\
\text { Technical } \\
\text { Consultation }\end{array}$ & $\begin{array}{l}\text { Observation, } \\
\text { Videotaping, and } \\
\text { 1-on-1 Consulting }\end{array}$ & $\begin{array}{l}\text { Consultant/ } \\
\text { Therapist/ } \\
\text { Advisor }\end{array}$ & $\begin{array}{l}\text { Clients or } \\
\text { Advisees }\end{array}$ \\
\hline $\begin{array}{l}\text { Coaching/ } \\
\text { Mentorship }\end{array}$ & $\begin{array}{l}\text { Observation, } \\
\text { Informal and } \\
\text { Structured } \\
\text { Conversations }\end{array}$ & $\begin{array}{l}\text { Organizer } \\
\text { "Matchmaker" }\end{array}$ & $\begin{array}{l}\text { Partners: } \\
\text { Master Teachers } \\
\text { Apprentices }\end{array}$ \\
\hline
\end{tabular}




\section{What is Classroom Research?}

By this time, many readers will have heard K. Patricia Cross speak on Classroom Research at a national conference or read one of her several articles on the subject. Those readers may wish to turn ahead to the next section. For those not completely familiar with the concept, however, the discussion below may be useful.

Classroom Research is not a brand name, nor is it a wholly new concept. Many faculty developers and teachers across the country have been engaged in "Classroom Research-like" efforts, independent of one another, for years. Three years ago, Chism and Sanders (1986) discussed a similar concept, which they called "practice-centered inquiry." In this same journal, just last year, Erickson and Erickson (1988) introduced several faculty reports from a "Classroom Research Program" at the University of Rhode Island. No doubt there are many other similar efforts underway. While the remarks on Classroom Research below refer only to the project that Pat Cross and I are directing at the University of California, Berkeley, many of the basic concepts are common to instructional improvement programs across the country.

The primary purpose of Classroom Research is to improve the quality of learning in college classrooms by improving the effectiveness of teaching. The U.C. Berkeley Classroom Research Project assists individual college teachers in obtaining feedback on what, how much, and how well their students are learning while courses are in progress. Teachers then use that information to refocus on their teaching to improve learning. As faculty practice Classroom Research, they become better able to understand and promote learning. These Classroom Researchers also increase their ability to help the students themselves become more effective, self-directed learners. In brief, the Classroom Research project aims to empower both teachers and students to improve the quality of college learning.

The Classroom Research Project has roots in three widespread approaches to improving higher education: the assessment movement, research on teaching and learning, and instructional development. In each case, however, the Classroom Research Project seeks to bring the benefits of these approaches into the college classroom and under the direction of the individual teacher. First, it brings assessment, usually practiced at the system or campus level, directly into classrooms, where the teaching and learning mission of colleges is carried out. Second, Classroom Research seeks to reduce the gap between research on teaching and learning and teaching practice to zero by providing teachers with tools needed to 
conduct action-oriented, applied research in their own classrooms. Third, Classroom Research expands the scope of instructional development by encouraging teachers not only to apply innovative teaching techniques, but also to assess systematically the effects of those innovations on student learning.

All good teachers gather information on their students' learning, of course, but very few do so systematically and regularly enough to use that feedback to improve the quality of learning. Furthermore, much of the information college teachers collect is used for summative evaluation. It comes in the form of tests, assigned papers, and term projects, and is used to sort and grade students at the end of units or courses, too late to affect learning.

Most experienced teachers are fairly adept at summative assessment, at grading and sorting, even if it is far from a pleasant task for many. In contrast, most college teachers are not as skilled at formative assessment, defined as getting information early and regularly enough to avoid or defuse learning problems and keep learners on track. Much of the feedback teachers depend on to make ongoing, formative assessments of student learning and on-line, lightning-fast adjustments in their teaching is diffuse and quickly lost. Examples of this evanescent data are insights to be gained from student questions and the valuable information contained in a lively class discussion. In sum, while most faculty know pretty well how to determine whether or not students have learned and how much they have learned, they are much less skilled at assessing how and how well students are learning, or why they are not, on a day-to-day basis.

\section{How Classroom Research Works}

One of the primary goals of Classroom Research is to help teachers develop simple ways to investigate, document, and analyze student learning in progress. To do this, faculty must learn to focus, collect, and make sense of the feedback they elicit in the classroom. The U.C. Berkeley Classroom Research Project, jointly funded by the Pew Charitable Trusts and the Ford Foundation, offers college faculty a step-by-step process for learning to carry out simple Classroom Research projects.

We refer to these first-stage projects, designed to assess student achievement of a single important course goal, as Classroom Assessment. Over the course of a semester, participating faculty work through a ten-step process we call the Classroom Assessment Project Cycle. Though the listing of steps in Figure 2 may make it seem daunting, in practice it is 
a simple, relatively quick process. In fact, many participants have worked through this cycle two or three times in their first semester of involvement.

The initial Classroom Assessment training is carried out in a one-day, six-to-eight-hour-long workshop. In the introductory workshop session, participants use a specially designed goals survey, the "Teaching Goals Inventory," to identify and rank their course goals. This exercise encourages participating teachers to focus on assessing one important teaching/learning goal in one course. No attempt is made to guide the teacher's choice of a focus goal, but thus far, many more teachers have focused on skill- or process-related goals than on goals concerned with the specific informational content of their courses.

Once faculty members have selected a particular course and teaching goal to assess, they consider the kinds of feedback they might collect on

\section{FIGURE 2}

\section{A Classroom Assessment Project Cycle: What Participants Do}

1. Choose one class to focus on, a class that presents teaching/learning problems or questions that are challenging but tractable;

2. Identify and clarify teaching/learning goals for that "focus" class;

3. Adapt or develop simple techniques for assessing one of those critical goals and plan a simple Classroom Assessment project;

4. Teach to the goal that is being assessed;

5. Assess student achievement of that goal by carrying out the planned project and collecting data;

6. Analyze (study) the data collected through the assessment project;

7. Interpret the results of the data analysis and their implications for future teaching and learning in the focus class, and plan an appropriate response to the feedback;

8. Tell the students what the results are and what the planned response is;

9. Evaluate the project's effects on student learning; and, if appropriate;

10. Design a follow-up project and start the cycle again. 
student learning related to their goals. They then identify techniques they might use to get that feedback. Many of the participants begin by adapting one of the assessment techniques from Classroom Assessment Techniques: A Handbook for Faculty (Cross and Angelo, 1988). Faculty are encouraged, however, to design and field-test assessment techniques of their own devising, techniques specially tailored to their disciplines, curricula, and students. As a result, after modeling their first assessment techniques on those in the Handbook, several teachers have gone on to create their own ingenious feedback devices.

Although teachers are free to carry out their projects independently, almost none have chosen to do so. Over and over, the participants report that discussing teaching and learning problems with their colleagues, particularly those from their own departments, is one of the most valuable outcomes of their involvement. The most effective working arrangements to date have involved pairs or small teams of teachers from the same or like disciplines getting together as needed to discuss their projects and assist each other. When all or most of the participants on a given campus have completed a project cycle, the whole group convenes for reporting out. This generally happens twice during the semester, at the midpoint and near the end. After their initial work in within-discipline teams, faculty from various disciplines seem ready and eager to learn from each other, and able to draw analogies to projects and problems from fields other than their own.

The teachers in our 1988-1989 Project, more than one hundred faculty on four community college and two private four-year college campuses, were almost universally anxious to investigate larger questions than a single Classroom Assessment project could answer. Once participants feel comfortable with Classroom Assessment, they are encouraged to design more thorough, longer-term projects to study their larger questions. These more ambitious projects, some of which may continue for a year or more, represent true Classroom Research efforts. As such, they often incorporate Classroom Assessment techniques, but go beyond them. Thus, a Classroom Research project is more than the sum of individual Classroom Assessment projects. It is the continuous, ongoing, developing study of teaching and learning in the classroom through a wide variety of appropriate, teacher-developed means.

Classroom Assessment happens to be our most clearly elaborated tool in the Classroom Research "toolbox" so far, but there are many other ways "in" that need to be explored. For example, interested Classroom Researchers could mine the rich information on development of critical 
and creative thinking that is buried in classroom tests and homework assignments, term papers, and problem sets. Others could develop more effective ways to use short, focused interviews and surveys to assess the effects of course activities on beliefs, values, and dispositions. Still other Classroom Research projects could focus on better using existing student evaluations. To fulfill its promise, Classroom Research must become a vehicle for understanding and improving the entire range of learning goals that college teachers have for their students and that students have for themselves.

\section{Classroom Research as Faculty Development: A Sixth Approach To Instructional Improvement}

Earlier in this article, I proposed seven guidelines to improve the quantity and quality of faculty involvement in instructional development programs. I then briefly described five well-established faculty development approaches to improving teaching and learning. Next, I discussed Classroom Research as a sixth possible approach. Let us now compare these six instructional development approaches in terms of whether they normally follow the seven suggested guidelines for success. In Figure 3 below, each of the approaches is rated in terms of its adherence to each guideline. If a given approach generally adheres to a given guideline in practice, it will rate a plus sign ( + ); if it does not, it will rate a minus sign $(-)$. In cases where practice is clearly mixed, combined signs will be used $(+1-)$.

If Figure 3 is an accurate appraisal of these approaches, Classroom Research is an approach to faculty development that adheres well to the guidelines suggested earlier in this article, and thus is likely to encourage more widespread and effective faculty participation. While I admit to the possibility of being biased in favor of an approach I am heavily invested in, I do recognize areas in which Classroom Research is still lacking.

For example, although Classroom Research is designed to capitalize on disciplinary expertise, the most effective methods for doing so have not yet been worked out in practice. The same can be said of the ongoing efforts to make Classroom Research more substantive by linking it to the existing research base. In addition, a small number of faculty on each participating campus have expressed concerns that suggest that even Classroom Research sometimes threatens faculty status and autonomy. Efforts to make Classroom Research conform more closely to these guidelines are moving ahead, but are not yet fully realized. Nevertheless, 


\section{FIGURE 3}

Comparing Six Approaches to Instructional Development in Terms of Adherence/Non-Adherence to the Proposed Guidelines

\begin{tabular}{|c|c|c|c|c|c|c|}
\hline Guidelines & $\begin{array}{l}\text { Information/ } \\
\text { Inspiration }\end{array}$ & $\begin{array}{l}\text { Rewards } \\
\text { and } \\
\text { Recognition }\end{array}$ & $\begin{array}{l}\text { Specific } \\
\text { Skills } \\
\text { Training }\end{array}$ & $\begin{array}{l}\text { Clinical/ } \\
\text { Technical } \\
\text { Consultation }\end{array}$ & $\begin{array}{l}\text { Peer- } \\
\text { Coaching/ } \\
\text { Mentorship }\end{array}$ & $\begin{array}{l}\text { Classroom } \\
\text { Research }\end{array}$ \\
\hline
\end{tabular}

1. Focus on Improving Learning?

$$
+1-
$$$$
-
$$

$+1-$

$+1-$

$+1-$

$+$

2. Develop Faculty Skills in Assessing Learnng?

$$
-
$$

$+1-$

$+1-$

$+1-$

$+$

3. Respect and Capitalize on Disciplinary "Ways of

$+1-$

$-$

$+1-$

$+1-$

$+1-$

$+$ 


\section{FIGURE 3 (Continued)}

\begin{tabular}{|c|c|c|c|c|c|c|}
\hline Guidelines & $\begin{array}{l}\text { Information/ } \\
\text { Inspiration }\end{array}$ & $\begin{array}{l}\text { Rewards } \\
\text { and } \\
\text { Recognition }\end{array}$ & $\begin{array}{l}\text { Specific } \\
\text { Skills } \\
\text { Training }\end{array}$ & $\begin{array}{l}\text { Clinical/ } \\
\text { Technical } \\
\text { Consultation }\end{array}$ & $\begin{array}{l}\text { Peer- } \\
\text { Coaching/ } \\
\text { Mentorship }\end{array}$ & $\begin{array}{l}\text { Classroom } \\
\text { Research }\end{array}$ \\
\hline
\end{tabular}

\section{Build in Personal}

Investment and Faculty

Ownership?

\section{Appeal to a Broad}

Range of Motivations?

6. Build in Intellectual Substance?

7. Plan and Implement for Long Term?
$+1-$

$-$

$-$
$+1-$

$+1-$

$$
-
$$

$+1-$

$+$

$+1-$

$+1-$

$+1-$

$+1-$

$+$

ton

$+1-$

$+1-$

$+1-$ 
with its clear strengths in building faculty and student self-awareness of learning, building in personal investment, and capitalizing on intrinsic motivation, Classroom Research offers many advantages to faculty developers.

Classroom Research as instructional development directly and explicitly draws on each of the other approaches, although less so in the case of Rewards and Recognition. In Classroom Research projects, the faculty developer provides inspiration, information, and specific skills training through the initial workshop. While technical and even clinical consultation may also be provided by the faculty developer, the participants play much more important roles as co-consultants during the course of the projects. Peer coaching and support are also central features of most campus projects, and some informal mentoring takes place.

There are two important differences, however, between Classroom Research and the other five approaches to instructional improvement. The first difference is one of focus. The primary purpose of Classroom Research is to bring about learning improvement. Therefore, it focuses on teaching improvement as a means to that end; only one of several possible means. The second difference is one of degree. To succeed, Classroom Research requires a much greater degree of faculty initiative, control, independence, and collaboration than do the other approaches.

At the 1988 POD Network Conference, after giving a brief progress report on the Classroom Research Project, I was asked a tough question by a colleague who had heard my presentation. This experienced and well-regarded faculty development specialist asked, "If Classroom Research really catches on, will there be any place in it for us faculty development folks?"

Although I assured her that faculty developers did have an important role to play in Classroom Research, I found it difficult at the time to define that role. Her question was really whether Classroom Research could fit into broader, ongoing faculty development efforts to improve teaching effectiveness. After a year of field-testing the approach, the answer seems much clearer, and it is emphatically positive.

The campus faculty development specialist has a crucial role to play in stimulating interest in Classroom Research, organizing the project, providing initial training, and supporting and encouraging individual and group initiatives. At the same time, however, the faculty developer must refrain from explicitly or implicitly setting the agenda for or directing the course of those projects. After the initial training workshop, the faculty 
developer's role in a Classroom Research program should be, first and foremost, as a facilitator, and, second, as a resource.

Classroom Assessment and Research projects often lead faculty to become aware of their needs for very specific information, skills training, consultation, and coaching. As faculty became more involved in pursuing Classroom Research and clearer about the kinds of help they and their students need, they become more motivated to seek help. Even though Classroom Researchers may turn first to their own experiences and then to that of their colleagues, it is quite likely that they will make more requests of faculty development programs than do their less involved peers and use faculty development resources more fully.

Faculty developers are uniquely prepared to help faculty meet these needs. By creating conditions in which college teachers become more explicitly aware of their students' learning and their own practice, Classroom Research can increase the frequency of well-focused, answerable requests, and optimize the effectiveness of the various services faculty developers offer. In this way, Classroom Research can serve a channeling or "triage" function within the broader teaching/learning improvement program. Through their Classroom Research projects, faculty discover and clarify what they need to teach better and what their students need to learn better, and can be directed to the appropriate resources - a great many of which are currently underutilized.

Although it is still very much a developing approach, Classroom Research holds much promise for improving all four dimensions of learning quality mentioned in the introduction. On the most basic level, Classroom Research can help teachers help students improve the quality of their learning of the knowledge, skills, and values being taught in each course. At the same time, by actively participating in Classroom Research projects, both students and teachers can improve the quality of their self-awareness as learners. By assessing their teaching effectiveness, individual faculty members can continually improve their practical knowledge and teaching skills, deepening their understanding of their disciplines in the process. And, over the long term, by collaborating on Classroom Research projects and sharing lessons learned, college teachers can greatly improve the quality of what the profession as a whole knows about effective practice.

If we as faculty developers choose to make improving the quality of learning our primary goal for the 1990's, Classroom Research can help us succeed as individuals and help faculty development as a whole not only survive but thrive. 


\section{References}

Association of American Colleges. (1985). Integrity in the college curriculum: A report to the academic community. Washington, DC: Association of American Colleges.

Carnegie Council on Policy Studies in Higher Education. (1980). Three thousand futures. San Francisco, CA: Jossey-Bass.

Chism, N.V.N., and Sanders, D.P. (1986). The place of practice-centered inquiry in a faculty development program. In M. Svinicki, J. Kurfiss, and J. Stone (Eds.), To Improve the Academy, 5.

Cross, K.P., and Angelo, T.A. (1988). Classroom assessment techniques: A handbook for faculy. Ann Arbor, MI: National Center for Research to Improve Postsecondary Teaching and Learning, University of Michigan.

Eisner, E. (1985). Aesthetic modes of knowing. In Eisner, E. (Ed.), Learning and teaching the ways of knowing Eighty-Fourth Yearbook of the National Society for the Study of Education, Part II (pp. 23-26). Chicago, IL: The University of Chicago Press.

Erickson, G.R. (1986). A survey of faculty development practices. In M. Svinicki, J. Kurfiss, and J. Stone (Eds.), To Improve the Academy, 5.

Erickson, B.L., and Erickson, G.R. (1988). Notes on a classroom research program. In J. Kurfiss, L. Hilsen, S. Kahn, M.D. Sorcinelli, and R.B. Tiberius (Eds.), To Improve the Academy, 7.

Gamson, Z., and Chickering, A.W. (1987, March). Seven principles for good practice in undergraduate education. AAHE Bulletin, 5-10.

Mathis, B.C. (1982). Faculty development. In H.E. Mitzel (Ed.), Encyclopedia of educational research, Vol. 2 (pp. 646-655). New York, NY: The Free Press.

McKeachie, W.J. (1979). Perspectives from psychology: Financial incentives are ineffective for faculty. In D.R. Lewis and W.E. Becker, Jr. (Eds.), Academic rewards in higher education (pp. 3-20). Cambridge, MA: Ballinger.

McKeachie, W.J., Pintrich, P.R., Lin, Y.G., and Smith, D.F. (1986). Teaching and leaming in the college classroom: A review of the research literature. Ann Arbor, MI: National Center for Research to Improve Postsecondary Teaching and Learning, University of Michigan.

Murray, H.G. (1985). Classroom teaching behaviors related to college teaching effectiveness. In J.G. Donald and A.M. Sullivan (Eds.), Usingresearch to improve teaching: New directions for teaching and leaming No. 23. San Francisco, CA: Jossey-Bass.

National Commission on Excellence in Education. (1983). A nation at risk. Washington, DC: U.S. Department of Education. 